\title{
Cow-level factors associated with subclinical hypocalcemia at calving in multiparous Jersey cows
}

\author{
A. Valldecabres, ${ }^{1}$ J. A. A. Pires,${ }^{2}$ and N. Silva-del-Río ${ }^{1,3 *}$ \\ ${ }^{1}$ Veterinary Medicine Teaching and Research Center, 18830 Road 112, Tulare, CA 93274 \\ ${ }^{2}$ INRA, Université Clermont Auvergne, VetAgro Sup, UMR1213 Herbivores, F-63122 Saint-Genes-Champanelle, France \\ ${ }^{3}$ Department of Population Health and Reproduction, School of Veterinary Medicine, University of California, Davis 95616
}

\section{ABSTRACT}

The objective of our study was to identify cow-level factors associated with subclinical hypocalcemia at calving $(\mathrm{SCH})$ in multiparous Jersey cows. A total of 598 Jersey and 218 Jersey $\times$ Holstein crossbreed cows from 2 commercial dairy herds were enrolled in a retrospective cohort study. Blood samples to determine total $\mathrm{Ca}$ concentration were collected from the coccygeal vessels at $3 \mathrm{~h} 19 \mathrm{~min}( \pm 2 \mathrm{~h} 33 \mathrm{~min})$ after calving. We used 2 serum Ca concentration thresholds to define SCH: $<2.00 \mathrm{mmol} / \mathrm{L}(\mathrm{SCH}-2.00)$ and $<2.12$ $\mathrm{mmol} / \mathrm{L}$ (SCH-2.12). We evaluated the association of cow-level factors with SCH with multivariable Poisson regression models. Variables evaluated for association with $\mathrm{SCH}$ were herd; parity $(2,3$, and $\geq 4)$; breed; previous lactation length and 305-d mature-equivalent milk yield; previous lactation first test milk yield and last test somatic cell count; lengths of calving interval, gestation, dry, and close-up periods; body condition and locomotion scores at calving; calving ease; and calf sex for singletons. We categorized continuous variables into quartiles $(\leq 25$ th percentile, interquartile range and $\geq 75$ th percentile). The prevalence of $\mathrm{SCH}$ among Jersey cows was 40 (SCH-2.00) and 64\% (SCH-2.12). Jersey cows of higher parity had greater risk of SCH2.00 and SCH-2.12. The risk of SCH-2.12 was higher after birthing male calves. We also found a tendency for previous lactation length and previous lactation 305-d mature-equivalent milk yield effect to affect risk of SCH-2.12. The risk of SCH-2.12 was lower for cows that had a previous lactation length shorter than the 25th percentile compared with cows that had a previous lactation length within the interquartile range. The risk of SCH-2.12 was higher for cows that had a previous lactation 305-d mature-equivalent milk yield below the 25th percentile compared with cows that

Received December 19, 2018

Accepted May 14, 2019.

*Corresponding author: nsilvadelrio@ucdavis.edu had a previous lactation 305-d mature-equivalent milk yield above the 75 th percentile. Also, Jersey $\times$ Holstein crossbreed was associated with increased risk of SCH2.00. In the multivariable analysis, we observed no association between $\mathrm{SCH}$ and previous lactation first test milk yield; last test somatic cell count; lengths of calving interval, gestation, dry, and close-up periods; body condition and locomotion scores at calving; and calving ease. Our study identified parity, breed, calf sex, previous lactation length, and previous lactation 305-d mature-equivalent milk yield as cow-level factors associated with SCH in multiparous Jersey cows.

Key words: dairy cow, subclinical hypocalcemia, transition period, Jersey

\section{INTRODUCTION}

Subclinical hypocalcemia (SCH) affects 41 to $54 \%$ of multiparous cows within $48 \mathrm{~h}$ of parturition (serum $\mathrm{Ca}<2.00 \mathrm{mmol} / \mathrm{L}$; Reinhardt et al., 2011) and is associated with impaired neutrophil function, increased risk of disease (retained placenta, subclinical ketosis, displaced abomasum, metritis, and subclinical endometritis), reduced DMI, and decreased odds of pregnancy at first AI (Chapinal et al., 2011, 2012a; Martinez et al., 2012, 2014; Ribeiro et al., 2013; Rodríguez et al., 2017). Earlier studies (Houe et al., 2001; Oetzel, 2004) defined SCH as blood total $\mathrm{Ca}<2.00 \mathrm{mmol} / \mathrm{L}(8.0 \mathrm{mg} /$ $\mathrm{dL}$ ), but little scientific evidence has supported this threshold. Succeeding research, conducted mostly in Holstein cows, has suggested thresholds for $\mathrm{SCH}$ that range from 1.80 to $2.20 \mathrm{mmol} / \mathrm{L}$ of $\mathrm{Ca}$ (Chapinal et al., 2012a; Martinez et al., 2012; Venjakob et al., 2018). Varying blood-sampling times for $\mathrm{Ca}$ determination (Neves et al., 2018a), as well as the outcome used to identify the best predictive blood Ca threshold (Rodríguez et al., 2017), may explain the differences observed in the proposed thresholds. Currently, the most commonly used threshold for $\mathrm{SCH}$ is $2.12 \mathrm{mmol} / \mathrm{L} \mathrm{Ca}(8.5$ mg/dL; Oetzel, 2013; Amanlou et al., 2016; Martinez et al., 2016), but little is known about the most informa- 
tive thresholds to identify cows with $\mathrm{SCH}$ in breeds other than Holstein.

Cow-level factors, including breed, previous lactation, and peripartum information have been previously associated with clinical hypocalcemia (Curtis et al., 1984; Roche and Berry, 2006; Saborío-Montero et al., 2017). Similarly, a couple of studies in Holstein cows associated postpartum SCH with peripartum cow-level factors such as standing behavior and DMI (Jawor et al., 2012), or parity and locomotion score (Neves et al., 2017). Evidence suggests that cow-level information available at the time of calving, such as parity, production potential, body condition and locomotion scores, and gestation and dry period length could serve to segregate cows that are more likely to benefit from SCH prophylactic strategies (Oetzel and Miller, 2012; Martinez et al., 2016; Domino et al., 2017; Leno et al., 2018). In addition, recent studies suggest that the effects of postpartum oral Ca supplementation on serum Ca concentration (Valldecabres et al., 2018), health, and productive and reproductive outcomes (Leno et al., 2018) are affected by blood Ca concentration before treatment. However, identifying cows with $\mathrm{SCH}$ still poses a challenge; affordable cow-side tests to determine blood ionized $\mathrm{Ca}$ are under development, but specific requirements for their comprehensive calibration methodology may initially limit their on-farm use (Neves et al., 2018b). Alternatively, dairy producers may opt to screen cows based on cow-level factors associated with increased risk of $\mathrm{SCH}$.

Although greater odds of clinical hypocalcemia have been reported for Jersey cows compared with Holstein cows (Lean et al., 2006; Roche and Berry, 2006), no information is available about the cow-level factors associated with $\mathrm{SCH}$ for this breed. Our objective was to evaluate the associations of breed, previous lactation, and peripartum information with SCH at calving in multiparous Jersey cows.

\section{MATERIALS AND METHODS}

A retrospective cohort study was conducted as a part of a larger study approved by the University of California Davis Institutional Animal Care and Use Committee (\#18846).

\section{Study Population}

Multiparous Jersey and Jersey $\times$ Holstein crossbreed cows from 2 commercial dairy herds in California were enrolled as part of a larger study from November 2015 to May 2016 (herd 1) and from August to October 2016 (herd 2). Herd 1 was a dry-lot herd and milked 2,789
Jersey cows; herd 2 was a freestall herd and milked 9,989 Jersey and Jersey $\times$ Holstein crossbreed cows. Both herds moved dry cows to a close-up pen approximately 3 wk prior to their expected calving date. In herd 1 , close-up cows showing secondary signs of calving were moved to a prepartum pen and accommodated in individual calving pens bedded with straw once primary signs of calving were observed. In herd 2, cows calved in the close-up pen. Calves were separated from dams immediately after parturition in both herds. Close-up cows were offered a TMR containing anionic salts once a day in both herds. Samples of the close-up TMR were collected at the beginning and end of the study period for herd 1 and at the end of the study period for herd 2. Close-up TMR samples were collected from 5 different feed bunk locations at feeding time, composited, dried, ground and analyzed by wet chemistry (Cumberland Valley Analytical Services, Hagerstown, MD). The composition of the close-up TMR is presented in Table 1.

Table 1. Ingredients and nutrient composition of close-up rations

\begin{tabular}{lrr}
\hline Item & Herd 1 & Herd 2 \\
\hline Ingredient (\% of DM) & & \\
Alfalfa hay & \multicolumn{1}{c}{} \\
Canola & 17.40 & 23.76 \\
Close-up mineral & 3.10 & 11.88 \\
Corn silage & 38.00 & 19.51 \\
Limestone & 3.10 & - \\
Milo silage & - & 11.68 \\
Mineral mix & - & - \\
Rolled corn & 13.60 & 23.37 \\
Rumen-protected fat & - & 1.19 \\
Soy hulls & 14.90 & - \\
Straw & 9.30 & - \\
Zeolite & 0.60 & - \\
Nutrient composition ${ }^{1}$ (DM basis) & & \\
CP (\%) & 16.25 & 14.10 \\
Crude fat (\%) & 2.48 & 2.88 \\
ADF (\%) & 26.30 & 22.10 \\
Ash-free NDF (\%) & 37.75 & 31.50 \\
Lignin (\%) & 4.17 & 4.78 \\
Starch (\%) & 18.85 & 25.30 \\
Ash (\%) & 14.87 & 12.79 \\
Ca (\%) & 2.86 & 2.46 \\
P (\%) & 0.40 & 0.41 \\
Mg (\%) & 0.43 & 0.59 \\
K (\%) & 1.27 & 1.33 \\
S (\%) & 0.47 & 0.33 \\
Na (\%) & 0.13 & 0.25 \\
Cl (\%) & 0.92 & 1.46 \\
Fe (mg/kg) & 71.50 & 388.00 \\
Zn (mg/kg) & 21.00 & 28.00 \\
Cu (mg/kg) & -17.61 & -16.80 \\
DCAD (mEq/100 g) & & \\
\hline Wet \% & & \\
\hline
\end{tabular}

${ }^{1}$ Wet chemistry analysis (Cumberland Valley Analytical Services, Hagerstown, MD).

${ }^{2} \mathrm{DCAD}$ calculations were performed according to the following equation: DCAD $(\mathrm{mEq} / 100 \mathrm{~g})=[(\mathrm{Na}+\mathrm{K})-(\mathrm{Cl}+\mathrm{S})]$. 


\section{Experimental Design and Data Collection}

A total of 598 Jersey (herd $1, \mathrm{n}=365$; herd $2, \mathrm{n}=$ $233)$ and 218 Jersey $\times$ Holstein crossbreed multiparous cows (herd 2) were enrolled in the present study.

Coccygeal blood samples were collected using evacuated tubes without anticoagulant (BD Vacutainer, Trace Element Serum; BD, Franklin Lakes, NJ) at 2 h 55 min \pm 2 h 10 min [mean \pm standard deviation (SD); herd 1] and $3 \mathrm{~h} 26 \mathrm{~min} \pm 2 \mathrm{~h} 24$ min after calving (mean $\pm \mathrm{SD}$; herd 2). Immediately after they were drawn, samples were placed in a portable refrigerator set at $4^{\circ} \mathrm{C}$ and transported to the laboratory within 3 $\mathrm{h}$ after collection. Samples were centrifuged at 1,430 $\times$ $g$ for 15 min at $15^{\circ} \mathrm{C}$ and serum was stored at $-20^{\circ} \mathrm{C}$ until analysis. Frozen serum samples were shipped to the California Animal Health Food Safety Laboratory (University of California, Davis) for total Ca determination by inductively coupled plasma-optical emission spectrometry (Melton et al., 1990). The intra-assay and inter-assay coefficients of variation were 2.0 and $4.4 \%$, respectively. Cows were scored for body condition and locomotion at calving by a single researcher, using a scale of 1 to 5 with 0.25 increments for BCS (Ferguson et al., 1994) and a 4-point scale for locomotion (adapted from Sprecher et al., 1997).

We obtained data on previous lactation length and 305-d mature-equivalent milk yield; previous lactation first test milk yield and last test SCC; gestation length; dry-off and close-up dates; parity; breed; calving time; calf sex; twin births; and calving ease from DairyComp305 (Valley Ag Software, Tulare, CA), the DHIA system (AgriTech Analytics, Visalia, CA) and on-farm spreadsheet records.

\section{Statistical Analyses}

All statistical analyses were performed with SAS version 9.4 (SAS Institute Inc., Cary, NC). Two thresholds of serum Ca were chosen for the analysis: $2.00 \mathrm{mmol} / \mathrm{L}$ (SCH-2.00; $8.0 \mathrm{mg} / \mathrm{dL}$ ), based on earlier definitions of SCH (Houe et al., 2001; Oetzel, 2004); and $2.12 \mathrm{mmol} / \mathrm{L}$ (SCH-2.12;8.5 mg/dL), used in recent research (Amanlou et al.,2016; Martinez et al., 2016; Valldecabres et al., 2018) based on its association with metritis, milk yield losses, and displaced abomasum (Chapinal et al., 2012b; Martinez et al., 2012; Rodríguez et al., 2017).

Continuous data were screened for outliers $( \pm 3$ SD from the herd mean). Cows with an outlier observation for any of the considered predictors [previous lactation length $(\mathrm{n}=5)$, previous lactation 305-d matureequivalent milk yield $(\mathrm{n}=1)$, length of gestation $(\mathrm{n}=$ $6)$, dry period $(\mathrm{n}=26)$, and close-up period $(\mathrm{n}=8)]$ were excluded from the data analysis. Excluded cows totaled 25 in herd 1 and 21 in herd 2 , so the final data set comprised 563 Jersey (herd 1, n $=340$; herd 2, $\mathrm{n}=223$ ) and 207 Jersey $\times$ Holstein crossbreed multiparous cows (herd 2). Variables and their respective number of observations considered for association with $\mathrm{SCH}$ at calving were as follows: parity $(2,3$, and $\geq 4$; $\mathrm{n}=554)$; herd $(\mathrm{n}=558)$; breed $(\mathrm{n}=425)$; previous lactation length $(\mathrm{n}=513)$ and 305 -d mature-equivalent milk yield $(\mathrm{n}=531)$; previous lactation first test milk yield $(\mathrm{n}=545)$ and last test SCC $(\mathrm{n}=481)$; gestation $(\mathrm{n}=500)$, dry $(\mathrm{n}=548)$ and close-up period $(\mathrm{n}=$ 410) lengths; calving interval $(\mathrm{n}=511)$; $\mathrm{BCS}(\leq 2.50$, $2.75-3.00$, and $\geq 3.25 ; \mathrm{n}=539)$ and locomotion score [not lame (scores 1 and 2) and lame (scores 3 and 4); n $=537$ at calving; calving ease (assisted and unassisted; $\mathrm{n}=485)$; twin births $(\mathrm{n}=544)$; and calf sex for singletons $(\mathrm{n}=524)$. We did not consider the calf sex of twin births, allowing only for evaluation of the univariable association of twin births and $\mathrm{SCH}$ at calving.

Descriptive statistics were generated using the MEANS, FREQ and TTEST procedures. To facilitate interpretation of the study outcomes and decrease potential collinearity between study variables, continuous variables were categorized as below or equal to the 25 th percentile (first quartile), within the interquartile range (25th to 75 th percentile) and above or equal to the 75 th percentile (fourth quartile).

Poisson regression analyses were conducted using the GENMOD procedure (Ospina et al., 2012). Underdispersion, indicated by deviance and Pearson Chi-square statistics, was addressed by fitting a Poisson regression with a robust error variance (Zou, 2004). First, we explored univariable associations between $\mathrm{SCH}$ at each of the studied thresholds and all possible explanatory variables by offering one variable at a time. Potential multicollinearity among the variables that had univariable association with SCH at $P<0.25$ was evaluated using the variance inflation factor option of the REG procedure; multicollinearity was not detected (highest variance inflation factor observed $=1.24$ ), so no variables were excluded from the analysis. Variables that had a univariable association with $\mathrm{SCH}$ at $P<0.25$ were considered covariates and offered to the multivariable Poisson regression models.

Separate multivariable models were built for each of the SCH thresholds considered. We formed final multivariable models via manual backward stepwise elimination when $P>0.10$ for a given variable. Pairwise interactions among remaining variables were evaluated and removed at $P>0.10$. Herd was treated as a fixed effect. The risk ratio and its Wald 95\% confidence interval (CI) were estimated for each explanatory variable remaining in the final models. The risk 
ratio represents the ratio of the probability of being diagnosed with $\mathrm{SCH}$ at calving following exposure, to the probability of being diagnosed with $\mathrm{SCH}$ without exposure. Categories with the highest frequency were set as referents (not exposed). Breed effect (Jersey vs. Jersey $\times$ Holstein) was evaluated for cows from herd 2, following the previously described method but adding breed as an explanatory variable for $\mathrm{SCH}$ at calving. Significance was declared at $P \leq 0.05$, and trends at $0.05<P \leq 0.10$ for all results. The accompanying figure was created using SigmaPlot (Systat Software Inc., San Jose, CA).

\section{RESULTS}

\section{Descriptive Statistics}

Our findings for the serum Ca concentration of multiparous Jersey cows by herd and parity group are presented in Figure 1. The prevalence of SCH-2.00 at $3 \mathrm{~h} 19$ min \pm 2 h 33 min (mean $\pm \mathrm{SD}$ ) after calving was $40 \%$ (herd 1, 50\%; herd 2, 24\%) and increased with parity; 19, 37, and $69 \%$ for Jersey cows in parities 2, 3 , and $\geq 4$, respectively. The prevalence of SCH- 2.12 reached $64 \%$ (herd 1,68\%; herd 2, 57\%) and resulted in 46,65 , and $85 \%$ of Jersey cows in parities 2,3 , and $\geq 4$, respectively.

\section{Cow-Level Factors Associated with SCH-2.00}

Results from univariable associations are presented in Table 2. Univariable associations with $\mathrm{SCH}$ were similar for both thresholds, with the exception of twinning, which tended to be associated with SCH-2.12 but not with SCH-2.00 $(P=0.36)$. Parity, BCS, herd, calf sex, breed, previous lactation 305-d mature-equivalent milk yield, previous lactation first test milk yield, and last test SCC were associated with SCH-2.00 and SCH2.12 at $P<0.10$. Locomotion score at calving, previous lactation length, dry and close-up period length, gestation length, calving interval, and calving ease were not associated with $\mathrm{SCH}$ at calving at any of the studied thresholds in the univariable analyses. Multivariable associations with $\mathrm{SCH}$ at calving are summarized in Table 3. The final multivariable model for SCH-2.00 included the effects of parity $(P<0.001)$ and herd $(P$ $<0.001)$. Compared with Jersey cows in parity 2 , those in parities 3 and $\geq 4$ were 1.9 (95\% CI, 1.3 to 2.6 ; $P<$ $0.001)$ and $3.3(95 \%$ CI, 2.5 to $4.4 ; P<0.001)$ times more likely to be below the threshold of $2.00 \mathrm{mmol} / \mathrm{L}$ $\mathrm{Ca}$, respectively. Similarly, the risk of SCH-2.00 was higher for Jersey cows in parity $\geq 4$ compared with those in parity 3 (risk ratio, $1.8 ; 95 \%$ CI, 1.4 to $2.2 ; P$

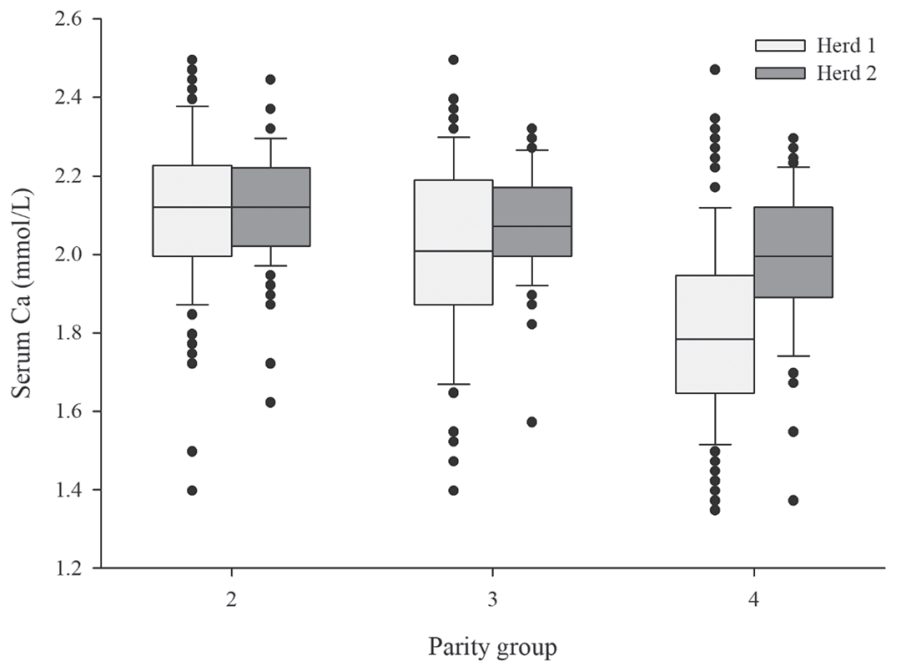

Figure 1. Box and whiskers plot of serum Ca concentration (mmol/L) for multiparous Jersey cows at 3 h 19 min (SD 2 h 33 min) after calving by parity group and herd. Parity group 2 was cows in their second lactation (herd $1, \mathrm{n}=126$; herd $2, \mathrm{n}=96$ ); group 3 was cows in their third lactation (herd $1, \mathrm{n}=88$; herd $2, \mathrm{n}=61$ ), and group 4 was cows of $\geq$ fourth lactation (herd $1, \mathrm{n}=126$; herd $2, \mathrm{n}=$ 57). Serum Ca concentration was lower for herd 1 parity groups $3(P$ $=0.02)$ and $4(P<0.001)$ than for herd 2 groups. In the box plots, the boundaries of the box closest to and farthest from the horizontal axis indicate the 25 th and 75 th percentiles, respectively; the line within the box indicates the median; whiskers above and below the box indicate the 10th and 90th percentiles; and points above and below the whiskers indicate outliers outside the 10th and 90th percentiles, respectively.

$<0.001)$. Jersey cows from herd 2 were less likely to be diagnosed with SCH-2.00 than those from herd 1 (risk ratio, $0.6 ; 95 \%$ CI, 0.4 to $0.7 ; P<0.001)$.

\section{Cow-Level Factors Associated with SCH-2.12}

Univariable associations with SCH-2.12 are presented in Table 2. The final multivariable model for SCH-2.12 included parity $(P<0.001)$, calf sex $(P=0.003)$, previous lactation length $(P=0.07)$, and previous lactation 305 -d mature-equivalent milk yield $(P=0.10)$ as categorical variables (Table 3 ). Compared with Jersey cows in parity 2 , those in parities 3 and $\geq 4$ were $1.4(95 \% \mathrm{CI}$, 1.2 to $1.8 ; P<0.001)$ and $1.8(95 \% \mathrm{CI}, 1.6$ to $2.2 ; P<$ 0.001) times more likely to be below the threshold of $2.12 \mathrm{mmol} / \mathrm{L} \mathrm{Ca}$, respectively. Accordingly, the risk of SCH-2.12 was higher for cows in parity $\geq 4$ compared to those in parity 3 (risk ratio, $1.3 ; 95 \%$ CI, 1.1 to $1.5 ; P$ $<0.001)$. Jersey cows that birthed male calves were 1.3 (95\% CI, 1.1 to $1.5 ; P=0.003$ ) times more likely to be diagnosed with SCH-2.12, compared to dams of female calves. The risk of SCH-2.12 for cows with a previous lactation length shorter than the 25th percentile was 0.8 times lower than for cows with a previous lacta- 
tion length within the interquartile range (95\% CI, 0.7 to $1.0 ; P=0.02$ ). Compared to cows with a previous lactation 305-d mature-equivalent milk yield above the 75th percentile, the risk of SCH-2.12 was higher (risk ratio, $1.2 ; 95 \%$ CI, 1.0 to $1.5 ; P=0.04$ ) for cows with a previous lactation $305-\mathrm{d}$ mature-equivalent milk yield below the 25th percentile.

\section{Breed}

Compared with Jersey cows, Jersey $\times$ Holstein crossbreed cows were 1.5 times more likely to be diagnosed with SCH-2.00 (95\% CI, 1.0 to $2.1 ; P=0.03)$ when controlling for parity, calf sex, and close-up period length. We did not observe the same association for SCH-2.12 $(P=0.16)$. Similarly, breed was associated with SCH-2.00 $(P=0.03)$ and tended to be associated with SCH-2.12 $(P=0.08)$ in the univariable analysis.

\section{DISCUSSION}

To the best of our knowledge, this is the first study to evaluate risk factors for $\mathrm{SCH}$ in Jersey cows. In the absence of published research on the association of blood Ca concentration and health, productive, and reproductive outcomes in Jersey cows, we choose the previously proposed $2.00 \mathrm{mmol} / \mathrm{L}(8.0 \mathrm{mg} / \mathrm{dL})$ and $2.12 \mathrm{mmol} / \mathrm{L}(8.5 \mathrm{mg} / \mathrm{dL})$ as thresholds for $\mathrm{SCH}$.

These thresholds had either been adopted with little scientific evidence or based on research conducted in Holstein cows. In addition, recent research shows that time relative to parturition (Neves et al., 2018a) and the outcome used to identify the best predictive blood Ca cutoff (Rodríguez et al., 2017) lead to identification of different blood $\mathrm{Ca}$ thresholds, making it difficult to establish a single threshold for SCH. Thus, results from the present study should be interpreted carefully,

Table 2. Univariable associations among cow-level factors and subclinical hypocalcemia at calving (serum Ca $<2.00$ and $<2.12 \mathrm{mmol} / \mathrm{L}$ ) in 563 multiparous Jersey cows ${ }^{1}$

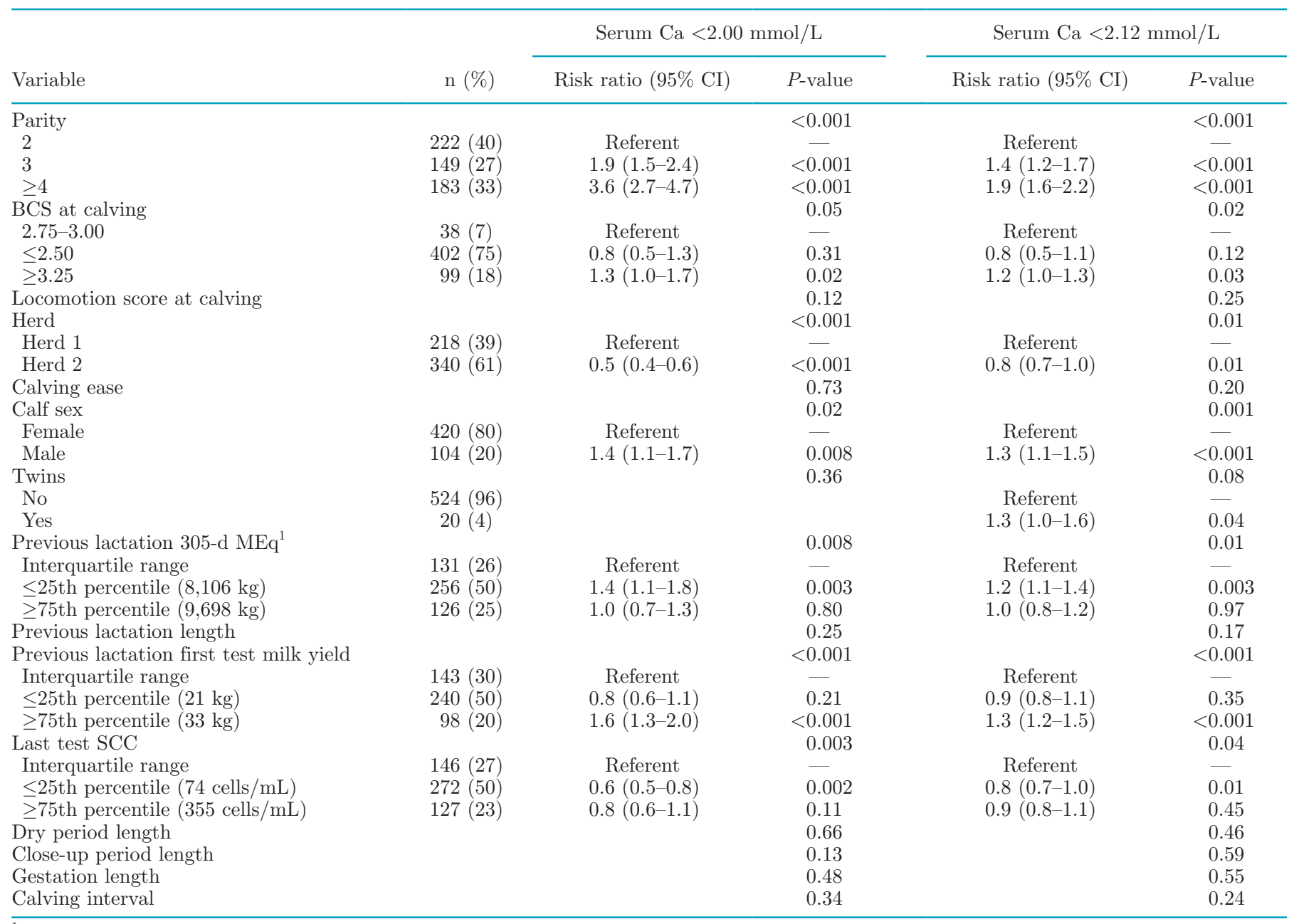

\footnotetext{
${ }^{1}$ Mature-equivalent milk yield.
} 
considering the limitations of the chosen thresholds and the time of SCH assessment.

In the present study, factors associated with $\mathrm{SCH}$ at calving in multiparous Jersey cows included parity, breed, calf sex, previous lactation length, and previous lactation 305-d mature-equivalent milk yield. We found little collinearity among variables showing univariable association with $\mathrm{SCH}$; however, it is likely that some of these variables explained similar variations in $\mathrm{SCH}$ and thus, did not remain in the final multivariable models. The reduced prevalence of lean and fat cows could explain why BCS was associated with SCH at calving in the univariable models but did not remain as explanatory variable in the multivariable models. However, in a previous study (Roche and Berry, 2006), the association between clinical hypocalcemia and BCS was also limited to a univariable association.

We observed a higher risk of SCH for older cows. Parity is a well-known risk factor for clinical hypocalcemia (Roche and Berry, 2006; Saborío-Montero et al., 2017) and SCH at calving (Neves et al., 2017). A decreased number of osteoblasts that are responsible for osteoclast activation after parathyroid hormone stimulation, decreased number and responsiveness of 1,25-dihydroxyvitamin D receptors in the intestine, and higher milk production in older cows have been proposed as explanatory mechanisms for the higher prevalence of hypocalcemia in older cows (Goff et al., 1991; Horst et al., 1997). Only multiparous cows were enrolled in the present study; thus, it is likely that the magnitude of the observed parity effect would have been larger if we had included first-parity cows in our study.
Herd effects are commonly associated with hypocalcemia in studies conducted with multiple herds (Chapinal et al., 2012b; Neves et al., 2017; Saborío-Montero et al., 2017). Many sources of variation are grouped under herd effect, and some might be associated with $\mathrm{SCH}$, such as feeding strategies or transition management. In the present study, herd 1 had a higher proportion of cows in parity $\geq 4$ (37 vs. $27 \%$ ) which, as shown in Figure 1, had lower serum Ca concentrations than those from herd 2. Moreover, the average parity for cows in parity $\geq 4$ was higher for herd 1 ( 4.5 vs. 4.0 for cows from herds 1 and 2, respectively).

Birthing male calves was identified as a significant risk factor for SCH-2.12. Both herds used sexed semen in their reproductive protocols, but we found no evidence that a reproductive management strategy based on cows' parity could have driven these results, because the frequency of cows birthing male calves did not differ among parity groups $(20,18$, and $21 \%$ for cows in parities 2,3 , and $\geq 4$, respectively; $P=$ 0.69). Nevertheless, as expected in herds using sexed semen, the proportion of male calves from a successful first AI (10\%) was lower than the overall proportion of male calves (20\%). Most likely, cows were inseminated with non-sexed semen after repeated breedings. This is supported by the observation that dams of males had calving intervals and previous lactations that were 58 and $38 \mathrm{~d}$ longer, respectively, than dams of females $(P$ $<0.001$ ); however, SCH at calving was not associated with calving interval, and the interaction between calf sex and previous lactation length was not significant in the present study. Furthermore, although dams of

Table 3. Multivariable associations among cow-level factors and subclinical hypocalcemia at calving (serum Ca $<2.00$ and $<2.12 \mathrm{mmol} / \mathrm{L}$ ) in 563 multiparous Jersey cows

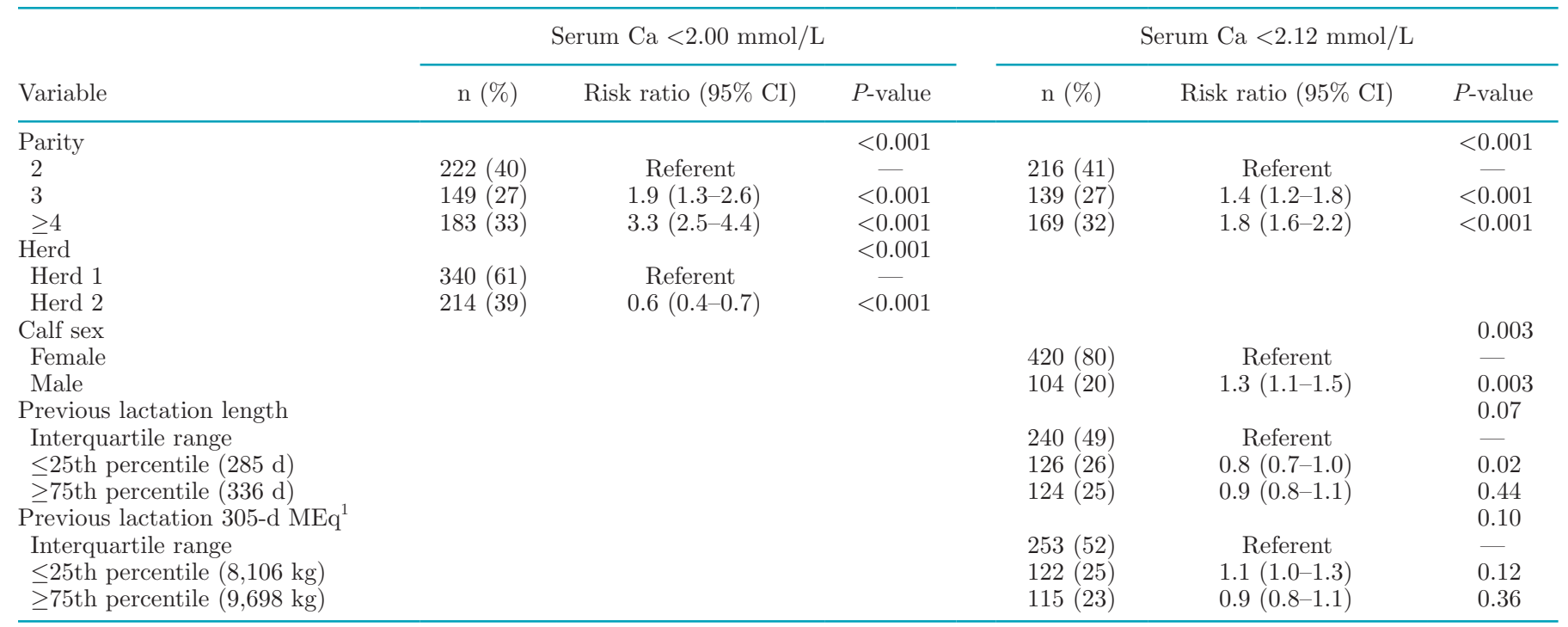

${ }^{1}$ Mature-equivalent milk yield. 
male calves had longer gestation lengths (males, $283 \mathrm{~d}$; females, $278 \mathrm{~d} ; P<0.001$ ) we observed no association between gestation length and $\mathrm{SCH}$ at calving. Previous studies have consistently reported higher birth weights for male than for female calves, as well as a greater risk of dystocia for dams of males (Kertz et al., 1997; Mee, 2008; Dhakal et al., 2013). In our study, we did not collect birth weight information, but dams of males were more frequently assisted at calving (21 vs. $8 \% ; P$ $<0.001)$. As well, dams of males are at a greater risk of other postpartum metabolic disorders such as hyperketonemia (McArt et al., 2013). It is plausible that greater gestation requirements and calving difficulty might boost $\mathrm{Ca}$ homeostasis challenges at parturition for dams of male calves.

Previous lactation length and previous lactation 305$\mathrm{d}$ mature-equivalent milk yield tended to be associated with SCH-2.12. We observed a lower risk of SCH-2.12 for cows with shorter previous lactation length and a higher risk of SCH-2.12 for cows with a lower previous lactation 305-d mature-equivalent milk yield. Results for previous lactation 305-d mature-equivalent milk yield seem contradictory, considering that as categorical variable, higher previous lactation milk yield has proven useful for identifying subpopulations that benefit from SCH prophylactic strategies (Oetzel and Miller, 2012; Martinez et al., 2016). However, Vergara et al. (2014) observed detrimental effects of longer previous lactation and protective effects of previous lactation milk yield on the odds of postpartum disease treatment and removal by 30 DIM. Based on a recent meta-analysis by Pryce et al. (2016), the genetic correlation of milk yield was unfavorable for clinical hypocalcemia, but the large confidence interval revealed a lack of consistency across published studies.

Breed was also a significant predictor of $\mathrm{SCH}$ at calving for cows from herd 2. We observed a higher risk of SCH-2.00 for Jersey $\times$ Holstein crossbreed cows than for Jersey cows. Nevertheless, although the prevalence of SCH-2.12 was numerically higher for Jersey $\times$ Holstein crossbreed than for Jersey cows (66 vs. 57\%), we did not observe the same association for SCH-2.12. Unpublished data from our laboratory shows a numerically higher first milking colostrum yield for Jersey $x$ Holstein crossbreed cows $(6.0 \mathrm{~kg} ; \mathrm{n}=17)$ compared with Jersey cows $(5.3 \mathrm{~kg} ; \mathrm{n}=22)$. Most likely, Ca requirements for colostrum synthesis at the onset of lactation drive the decrease in blood Ca concentration observed around calving. As a consequence of heterosis and a positive effect of crossbreeding on production traits (Sørensen et al., 2008), Jersey $\times$ Holstein crossbreed cows have greater constituents and milk yield than the parental breed average (Coffey et al., 2016). It is plausible that the combination of increased produc- tion with relatively higher milk constituents in Jersey $\times$ Holstein crossbreed cows makes them more susceptible to $\mathrm{SCH}$ at calving. In contrast, previous research in grazing cows reported the odds of developing clinical hypocalcemia as being 3.0 for Jersey and 2.5 for Jersey $\times$ Holstein crossbreed cows compared with Brown Swiss cows (Saborío-Montero et al., 2017) and 5.0 and 2.4 for Jersey and Jersey $\times$ Holstein crossbreed cows, respectively, compared with Holstein cows (Roche and Berry, 2006). Although comparisons in these studies were not made directly between Jersey and Jersey $x$ Holstein crossbreed cows, higher odds of clinical hypocalcemia were observed for Jersey cows. Dissimilarities in experimental design (grazing vs. TMR feeding systems or clinical hypocalcemia vs. SCH) may have driven these differences.

\section{CONCLUSIONS}

Our study identified parity, breed, calf sex, previous lactation length, and previous lactation 305-d matureequivalent milk yield as cow-level factors associated with the risk of $\mathrm{SCH}$ at calving in multiparous Jersey cows. Higher-parity cows had a greater risk of SCH2.00 and SCH-2.12. Birthing male calves was associated with a higher risk of SCH-2.12. We observed tendencies for lower and higher risk of SCH-2.12 for cows with a shorter previous lactation length and a lower previous lactation 305-d mature-equivalent milk yield, respectively. Also, Jersey $\times$ Holstein crossbreed cows had increased risk of SCH-2.00. The identified cow-level factors could be considered to segregate Jersey cows that are more likely to experience $\mathrm{SCH}$ and evaluate targeted prophylactic strategies.

\section{ACKNOWLEDGMENTS}

Financial support for this research was partially provided by Bio-Vet Inc. (Barneveld, WI). The authors appreciate the collaboration of Jer-Z-Boyz Ranch (Pixley, CA) and Pacific Rim Dairy (Corcoran, CA) in allowing us to use their facilities, cows, and records. We gratefully acknowledge support from Diego Rolle, Sonia Rodríguez, Sebastian Castaño, Victor José Ramírez (VMTRC, Tulare, CA) and Cedric Blanc (Pacific Rim Dairy) during sample and data collection. Special appreciation is extended to Bill Verboort from AgriTech Analytics for providing additional information used in the present study.

\section{REFERENCES}

Amanlou, H., A. P. Akbari, N. E. Farsuni, and N. Silva-del-Río. 2016. Effects of subcutaneous calcium administration at calving on min- 
eral status, health, and production of Holstein cows. J. Dairy Sci. 99:9199-9210. https://doi.org/10.3168/jds.2015-10844.

Chapinal, N., M. Carson, T. F. Duffield, M. Capel, S. Godden, M. W. Overton, J. E. P. Santos, and S. J. LeBlanc. 2011. The association of serum metabolites with clinical disease during the transition period. J. Dairy Sci. 94:4897-4903. https://doi.org/10.3168/jds 2010-4075.

Chapinal, N., M. E. Carson, S. J. LeBlanc, K. E. Leslie, S. Godden, M. Capel, J. E. P. Santos, M. W. Overton, and T. F. Duffield. 2012a. The association of serum metabolites in the transition period with milk production and early-lactation reproductive performance. J. Dairy Sci. 95:1301-1309. https://doi.org/10.3168/jds.2011-4724.

Chapinal, N., S. J. LeBlanc, M. E. Carson, K. E. Leslie, S. Godden, M. Capel, J. E. P. Santos, M. W. Overton, and T. F. Duffield. 2012b. Herd-level association of serum metabolites in the transition period with disease, milk production, and early lactation reproductive performance. J. Dairy Sci. 95:5676-5682. https://doi.org/10 $.3168 /$ jds.2011-5132.

Coffey, E. L., B. Horan, R. D. Evans, and D. P. Berry. 2016. Milk production and fertility performance of Holstein, Friesian, and Jersey purebred cows and their respective crosses in seasonal-calving commercial farms. J. Dairy Sci. 99:5681-5689. https://doi.org/10 $.3168 /$ jds.2015-10530.

Curtis, C. R., H. N. Erb, C. J. Sniffen, and R. D. Smith. 1984. Epidemiology of parturient paresis: Predisposing factors with emphasis on dry cow feeding and management. J. Dairy Sci. 67:817-825. https://doi.org/10.3168/jds.S0022-0302(84)81372-7.

Dhakal, K., C. Maltecca, J. P. Cassady, G. Baloche, C. M. Williams, and S. P. Washburn. 2013. Calf birth weight, gestation length, calving ease, and neonatal calf mortality in Holstein, Jersey, and crossbred cows in a pasture system. J. Dairy Sci. 96:690-698. https://doi.org/10.3168/jds.2012-5817.

Domino, A. R., H. C. Korzec, and J. A. McArt. 2017. Field trial of 2 calcium supplements on early lactation health and production in multiparous Holstein cows. J. Dairy Sci. 100:9681-9690. https:// doi.org/10.3168/jds.2017-12885.

Ferguson, J. D., D. T. Galligan, and N. Thomsen. 1994. Principal descriptors of body condition score in Holstein cows. J. Dairy Sci. 77:2695-2703. https://doi.org/10.3168/jds.S0022-0302(94)77212 $-\mathrm{X}$.

Goff, J. P., T. A. Reinhardt, and R. L. Horst. 1991. Enzymes and factors controlling vitamin D metabolism and action in normal and milk fever cows. J. Dairy Sci. 74:4022-4032.

Horst, R. L., J. P. Goff, T. A. Reinhardt, and D. R. Buxton. 1997. Strategies for preventing milk fever in dairy cattle. J. Dairy Sci. 80:1269-1280. https://doi.org/10.3168/jds.S0022-0302(97)76056 $-9$.

Houe, H., S. Østergaard, T. Thilsing-Hansen, R. J. Jørgensen, T. Larsen, J. T. Sørensen, J. F. Agger, and J. Y. Blom. 2001. Milk fever and subclinical hypocalcaemia-an evaluation of parameters on incidence risk, diagnosis, risk factors and biological effects as input for a decision support system for disease control. Acta Vet. Scand. 42:1-29.

Jawor, P. E., J. M. Huzzey, S. J. LeBlanc, and M. A. G. von Keyserlingk. 2012. Associations of subclinical hypocalcemia at calving with milk yield, and feeding, drinking, and standing behaviors around parturition in Holstein cows. J. Dairy Sci. 95:1240-1248. https://doi.org/10.3168/jds.2011-4586.

Kertz, A.F., L. F. Reutzel, B. A. Barton, and R. L. Ely. 1997. Body weight, body condition score, and wither height of prepartum Holstein cows and birth weight and sex of calves by parity: A database and summary. J. Dairy Sci. 80:525-529. https://doi.org/10.3168/ jds.S0022-0302(97)75966-6.

Lean, I. J., P. J. DeGaris, D. M. McNeil, and E. Block. 2006. Hypocalcemia in dairy cows: meta-analysis and dietary cation anion difference theory revisited. J. Dairy Sci. 89:669-684. https://doi .org/10.3168/jds.S0022-0302(06)72130-0.

Leno, B. M., R. C. Neves, I. M. Louge, M. D. Curler, M. J. Thomas, T. R. Overton, and J. A. A. McArt. 2018. Differential effects of a single dose of oral calcium based on postpartum plasma calcium concentration in Holstein cows. J. Dairy Sci. 101:3285-3302. https: //doi.org/10.3168/jds.2017-13164.

Martinez, N., C. A. Risco, F. S. Lima, R. S. Bisinotto, L. F. Greco, E. S. Ribeiro, F. Maunsell, K. Galvão, and J. E. P. Santos. 2012. Evaluation of peripartal calcemic status, energetic profile, and neutrophil function in dairy cows at low or high risk of developing uterine disease. J. Dairy Sci. 95:7158-7172. https://doi.org/10 $.3168 /$ jds.2012-5812.

Martinez, N., L. D. P. Sinedino, R. S. Bisinotto, R. Daetz, C. A. Risco, K. N. Galvão, W. W. Thatcher, and J. E. P. Santos. 2016. Effects of oral calcium supplementation on productive and reproductive performance in Holstein cows. J. Dairy Sci. 99:8417-8430. https:/ /doi.org/10.3168/jds.2015-10529.

Martinez, N., L. D. P. Sinedino, R. S. Bisinotto, E. S. Ribeiro, G. C. Gomes, F. S. Lima, L. F. Greco, C. A. Risco, K. N. Galvão, D. Taylor-Rodriguez, J. P. Driver, W. W. Thatcher, and J. E. P. Santos. 2014. Effect of induced subclinical hypocalcemia on physiological responses and neutrophil function in dairy cows. J. Dairy Sci. 97:874-887. https://doi.org/10.3168/jds.2013-7408.

McArt, J. A. A., D. V. Nydam, and G. R. Oetzel. 2013. Dry period and parturient predictors of early lactation hyperketonemia in dairy cattle. J. Dairy Sci. 96:198-209. https://doi.org/10.3168/ jds.2012-5681.

Mee, J. F. 2008. Prevalence and risk factors for dystocia in dairy cattle: A review. Vet. J. 176:93-101. https://doi.org/10.1016/j.tvjl .2007.12.032.

Melton, L. A., M. L. Tracy, and G. Möller. 1990. Screening trace elements and electrolytes in serum by inductively-coupled plasma emission spectrometry. Clin. Chem. 36:247-250.

Neves, R. C., B. M. Leno, K. D. Bach, and J. A. A. McArt. 2018a. Epidemiology of subclinical hypocalcemia in early-lactation Holstein dairy cows: The temporal associations of plasma calcium concentration in the first 4 days in milk with disease and milk production. J. Dairy Sci. 101:9321-9331. https://doi.org/10.3168/ jds.2018-14587.

Neves, R. C., B. M. Leno, T. Stokol, T. R. Overton, and J. A. A. McArt. 2017. Risk factors associated with postpartum subclinical hypocalcemia in dairy cows. J. Dairy Sci. 100:3796-3804. https:// doi.org/10.3168/jds.2016-11970.

Neves, R. C., T. Stokol, K. D. Bach, and J. A. A. McArt. 2018b. Method comparison and validation of a prototype device for measurement of ionized calcium concentrations cow-side against a pointof-care instrument and a benchtop blood-gas analyzer reference method. J. Dairy Sci. 101:1334-1343. https://doi.org/10.3168/jds 2017-13779.

Oetzel, G. R. 2004. Monitoring and testing dairy herds for metabolic disease. Vet. Clin. North Am. Food Anim. Pract. 20:651-674. https://doi.org/10.1016/j.cvfa.2004.06.006.

Oetzel, G. R. 2013. Oral calcium supplementation in peripartum dairy cows. Vet. Clin. North Am. Food Anim. Pract. 29:447-455. https: //doi.org/10.1016/j.cvfa.2013.03.006.

Oetzel, G. R., and B. E. Miller. 2012. Effect of oral calcium bolus supplementation on early-lactation health and milk yield in commercial dairy herds. J. Dairy Sci. 95:7051-7065. https://doi.org/ 10.3168/jds.2012-5510.

Ospina, P. A., D. V. Nydam, and T. J. DiCiccio. 2012. The risk ratio, an alternative to the odds ratio for estimating the association between multiple risk factors and a dichotomous outcome. J. Dairy Sci. 95:2576-2584. https://doi.org/10.3168/jds.2011-4515.

Pryce, J. E., K. L. Parker Gaddis, A. Koeck, C. B. Heringstad, C. Egger-Danner, K. F. Stock, A. J. Bradley, and J. B. Cole. 2016. Invited review: Opportunities for genetic improvement of metabolic disease. J. Dairy Sci. 99:6855-6873. https://doi.org/10.3168/ jds.2016-10854.

Reinhardt, T. A., J. D. Lippolis, B. J. McCluskey, J. P. Goff, and R. L. Horst. 2011. Prevalence of subclinical hypocalcemia in dairy herds. Vet. J. 188:122-124. https://doi.org/10.1016/j.tvjl.2010.03.025.

Ribeiro, E. S., F. S. Lima, L. F. Greco, R. S. Bisinotto, A. P. A. Monteiro, M. Favoreto, H. Ayres, R. S. Marsola, N. Martinez, W. W. Thatcher, and J. E. P. Santos. 2013. Prevalence of periparturient 
diseases and impacts on fertility of seasonally calving grazing dairy cows supplemented with concentrates. J. Dairy Sci. 96:5682-5697. https://doi.org/10.3168/jds.2012-6335.

Roche, J. R., and D. P. Berry. 2006. Periparturient climatic, animal, and management factors influencing the incidence of milk fever in grazing systems. J. Dairy Sci. 89:2775-2783. https://doi.org/10 .3168/jds.S0022-0302(06)72354-2.

Rodríguez, E. M., A. Aris, and A. Bach. 2017. Associations between subclinical hypocalcemia and postparturient diseases in dairy cows. J. Dairy Sci. 100:7427-7434. https://doi.org/10.3168/jds .2016-12210.

Saborío-Montero, A., B. Vargas-Leitón, J. J. Romero-Zúñiga, and J. M. Sánchez. 2017. Risk factors associated with milk fever occurrence in grazing dairy cattle. J. Dairy Sci. 100:9715-9722. https:/ /doi.org/10.3168/jds.2017-13065.

Sørensen, M. K., E. Norberg, J. Pedersen, and L. G. Christensen. 2008. Invited review: Crossbreeding in dairy cattle: A Danish perspective. J. Dairy Sci. 91:4116-4128. https://doi.org/10.3168/jds.2008 $-1273$.

Sprecher, D. J., D. E. Hostetler, and J. B. Kaneene. 1997. A lameness scoring system that uses posture and gait to predict dairy cattle reproductive performance. Theriogenology 47:1179-1187. https:// doi.org/10.1016/S0093-691X(97)00098-8.

Valldecabres, A., J. A. A. Pires, and N. Silva-del-Río. 2018. Effect of prophylactic oral calcium supplementation on postpartum mineral status and markers of energy balance of multiparous Jersey cows. J. Dairy Sci. 101:4460-4472. https://doi.org/10.3168/jds.2017 $-12917$.

Venjakob, P. L., L. Pieper, W. Heuwieser, and S. Borchardt. 2018. Association of postpartum hypocalcemia with early-lactation milk yield, reproductive performance, and culling in dairy cows. J. Dairy Sci. 101:9396-9405. https://doi.org/10.3168/jds.2017-14202.

Vergara, C. F., D. Döpfer, N. B. Cook, K. V. Nordlund, J. A. A. McArt, D. V. Nydam, and G. R. Oetzel. 2014. Risk factors for postpartum problems in dairy cows: Explanatory and predictive modeling. J. Dairy Sci. 97:4127-4140. https://doi.org/10.3168/jds .2012-6440.

Zou, G. 2004. A modified Poisson regression approach to prospective studies with binary data. Am. J. Epidemiol. 159:702-706. https:// doi.org/10.1093/aje/kwh090. 